OPEN ACCESS

Edited by:

Banasri Hazra,

Jadavpur University, India

Reviewed by:

Sol Cristians,

National Autonomous University of

Mexico, Mexico

Ran Wang,

Tianjin Medical University, China

*Correspondence:

Douwe Dekker

d.dekker@umcutrecht.nl

Mohamed Amiche

mohamed.amiche@u-pec.fr

Specialty section:

This article was submitted to

Ethnopharmacology,

a section of the journal

Frontiers in Pharmacology

Received: 22 April 2019

Accepted: 07 November 2019

Published: 26 November 2019

Citation:

Bartels EJH, Dekker D and Amiche M (2019) Dermaseptins, Multifunctional Antimicrobial Peptides: A Review of

Their Pharmacology, Effectivity,

Mechanism of Action, and

Possible Future Directions.

Front. Pharmacol. 10:1421.

doi: 10.3389/fphar.2019.01421

\section{Dermaseptins, Multifunctional Antimicrobial Peptides: A Review of Their Pharmacology, Effectivity, Mechanism of Action, and Possible Future Directions}

\author{
Emiel Jacob Henri Bartels ${ }^{1}$, Douwe Dekker ${ }^{2 *}$ and Mohamed Amiche ${ }^{3 *}$ \\ ${ }^{1}$ University Medical Center, University Utrecht, Utrecht, Netherlands, ${ }^{2}$ Dutch Poisons Information Center, University Medical \\ Center Utrecht, Utrecht, Netherlands, ${ }^{3}$ Mondor Institute of Biomedical Research, INSERM U955 Team 7, School of \\ Medicine, University Paris Est Créteil, Créteil, France
}

Dermaseptins are a group of $\alpha$-helical shaped polycationic peptides isolated from the Hylid frogs, with antimicrobial effects against bacteria, parasites, protozoa, viruses in vitro. Besides, anti-tumor effects have been demonstrated. However, few animal experiments and no clinical trials have been conducted thus far. This review summarizes the current knowledge on the pharmacology, ethno pharmacology, effectivity against infectious pathogens and tumors cells and the mechanism of action of the Dermaseptins. Future research should focus on further clarification of the mechanisms of action, the effectivity of Dermaseptins against several cancer cell lines and their applicability in humans.

Keywords: dermaseptin, Phyllomedusa bicolor, peptide, amphibian, infectious, antimicrobial, tumor

\section{INTRODUCTION}

Dermaseptins (DRSs) are a family of peptides that are part of the skin secretions of several Hylid frogs, particularly from the Agalychnis and Phyllomedusa family (Nicolas and Amiche, 2006; Amiche et al, 2008). In 1991, the first DRS was identified and characterized as a peptide rich in basic amino acids with a high propensity to adopt an $\alpha$-helical structure in a hydrophobic medium (Mor et al, 1991). The DRS-S1 was purified by reverse phase high-pressure liquid chromatography (RP-HPLC) from a skin extract of the Phyllomedusa sauvagii and sequenced by Edman's method. By now, there are more than a hundred DRS-like peptides classified in the large family of DRSs that share a strong identity in the cDNA sequences encoding their biosynthetic precursors (Nicolas and El Amri, 2009).

DRSs are often classified as antimicrobial peptides (AMPs), since they show effectivity in vitro against some gram positive and gram negative bacteria, parasites, yeasts, protozoa, viruses and display immune modulatory effects (Mor et al., 1994a; Mor et al., 1994b; Strahilevitz et al., 1994; Charpentier et al., 1998; Brand et al., 2002; Navon-Venezia et al., 2002; Brand et al., 2006; Conceicao et al., 2006; Conlon et al., 2007; Leite et al., 2008; Galanth et al., 2009; Nicolas and El Amri, 2009; Jiang et al., 2014; Zairi et al., 2014; Huang et al., 2017). Beside these antimicrobial properties, DRSs show activity against several human cancer types (Charpentier et al., 1998; Conlon et al., 2007; Nicolas and El Amri, 2009; Galanth et al., 2009; Van Zoggel et al., 2012; Shi et al., 2016; Huang et al., 2017; Dos Santos et al., 2017; Zhu et al., 2018) and can therefore be classified as an anticancer peptide as well. 
In view of the current increasing bacterial resistance to conventional antibiotics (Laxminarayan et al., 2013) the demand for novel antibacterial pharmaceuticals is high. Likewise, there is a need for novel anti-tumor treatments as cancer is rapidly becoming the leading cause of death in the Western world and conventional therapeutics are both cytotoxic and prone to therapy resistance due to microevolution of the tumor tissue (Corrie, 2008; Colak and Medema, 2014).

The aim of this review is to summarize the current knowledge on DRSs, to elaborate on the ethnopharmacology, the potential therapeutic values with respect to their anti-microbial and antitumor potency, and to suggest future directions for research. We thereby restricted ourselves to DRSs (sensu stricto) according to the nomenclature proposed by Amiche et al. (2008).

\section{ETHNOPHARMACOLOGY IN PEPTIDE DISCOVERY}

Many plants and animal products have yet found their way from traditional use to Western medicine leading to the discovery of for example morphine, codeine, quinine, aspirin, curare, pilocarpine and ACE-inhibitors (Bisset, 1991; Alves and Alves, 2011; Dias et al., 2012). Likewise, DRS-B's from the Phyllomedusa bicolor secretions are yet known to be applied for human use in traditional medicine. This Phyllomedusa bicolor is an Amazonian amphibian found in the forests of Brazil, the Guianas, Venezuela, Colombia, Peru, and Bolivia. The secretions of this frog are referred to by 'Kambo,'Kampu, or 'Sapo', and are used by natives as a medicine and part of a cleansing ritual. The use of Kambo by South American Indians was first described by Constantin Tastevin in 1925 in the Kachinaua, Kurina, and the Kanamari tribes (De Lima and Labate, 2008). Later, the traditional use of kambo was also documented in the Katukina tribe, the Mayoruna tribe, and the Matse tribe (De Lima and Labate, 2008; Gorman, 2015). Other DRS secreting frogs have not been documented to be useful in rituals.

The Kambo-ritual is characterized by an immediate and short-lived physical response followed by a longer lasting mental and minor physical effects. The Indians 'harvest' the frog by collecting the secretion from a live frog and transfer its secretions to a bamboo stick. The medicine may then be used to cure or prevent illness, to expel 'panema' (bad spirit), or even to induce an abortion (Gorman, 2015). When unlucky in hunting Kambo reportedly increases stamina, and sharpens senses during long hunts. Application involves burning dots on the skin, usually on arms and/or legs, and sticking a small dose (10 mg) 'dot' on the open wound. The symptoms are severe and immediate; violent nausea, vomiting, diarrhea, edema of the face and headaches. Symptoms last until the secretion is removed from the wound usually after 15-20 minutes.

Besides its traditional use in the Amazon, Kambo has found its way into the Western alternative healing scene as well. While the reports on the beneficial effects of this ritual are numerous and range from relieving symptoms of pain syndromes, autoimmune diseases, skin disease, and cancer to substance abuse and depression (Hesselink, 2018), so are the accounts of adverse effects of participating in a rite, with or without experienced guidance. These include a transient syndrome of inappropriate antidiuretic hormone secretion (Leban et al., 2016), presumed drug induced liver injury in a chronic alcoholic (Pogorzelska and Lapinski, 2017), sudden death upon chronic kambo use in which autopsy revealed underlying heart disease possibly related to reduced myocardial perfusion (Aquila et al., 2018) and delayed kambo related symptoms in a 24 -year-old woman 22 hours after the ritual (Li et al., 2018).

The short-lasting effects of kambo are related to a diversity of biologically active peptides besides DRS including Phyllokinin (a bradykinin), Phyllomedusa (a tachykinin), Sauvagine (vasodilator), Caerulin (a CCK like peptide) and Deltorphin/ Demorphin (opioid receptor agonists). Studies on these peptides have contributed greatly to our knowledge concerning the $\mu / \delta$-opioid and serotonin receptor (Erspamer et al., 1993), but are beyond the scope of this review. Many of the immediate effects of Kambo can be explained by peptides in the frogsecretion. Vasoactive properties of some of these peptides for example might contribute to the rapid absorption of the secretion into the fresh burn. Amongst these peptides, DRS is the primary candidate for the anti-microbial effects reported upon the use of Kambo.

\section{STRUCTURAL AND PHARMACOLOGICAL ANALYSIS OF THE DRS FAMILY}

Even though each DRS has a unique amino acid sequence and selectivity patterns towards microorganisms and tumors, there are also a lot of pharmacological similarities. Figure 1 shows the amino acid sequence alignment of 57 DRSs sequences extracted from the antimicrobial peptide databases (http://aps.unmc.edu/AP/main.php). There is amino-acid sequence similarity within DRS from the same frog (DRS-B1B6; 33-62\%) (Charpentier et al., 1998), but also between DRS from different species (DRS-B1 and DRS-S1; 81\%, DRS-B2, and DRS-D 84.8\%) (Mor et al., 1994b; Auvynet et al., 2008). They are mostly rather short peptides (21-34 residues) with a highly-preserved tryptophan residue on the 3rd position from the N-terminus (Nicolas and El Amri, 2009) except for DRS-S10, DRS-S13, DRS-C3, and DRS-A4. DRSs can be fitted into an amphipathic $\alpha$-helix with their hydrophobic residues on one face and the polar cationic residues in cluster on the opposite face. They usually do this is an anionic environment, or under the influence of certain phospholipids (Hoskin and Ramamoorthy, 2008). These charged clusters tend to differ among DRS, for example; DRS-B1 has a narrow polar face of a mean radial angle of $115^{\circ}$, DRS-B2 has a polar face covering almost half of the helix; $175^{\circ}$ and DRS-S1 a polar face of $145^{\circ}$ (Mor et al., 1994a). Furthermore, they show great variation in net charge and density of charge. DRS-S9 seems to be an exception as it has a highly hydrophobic core flanked by cationic residues (Lequin et al., 2006; Caillon et al., 2013). Thus far, several DRS have been in vitro tested for their activity against various microorganisms (Lorin et al., 2005; Savoia et al., 2010; de Moraes et al., 2011; van Zoggel et al., 


\begin{tabular}{|c|c|c|c|}
\hline NAMES & SEQUENCES & SIZES & REFERENCES \\
\hline DRS-S10 & GLVSDLLSTVTG-------LLGNLGGGGLKKI-------- & 25 & Lequin et al, 2006 \\
\hline DRS-S13 & GLRSKIKEAA--------KTAGKMALGFVNDMA------- & 25 & Lequin et al, 2006 \\
\hline DRS-S12 & GLWSKIKEAA--------KTAGKMAMGFVNDMV------- & 25 & Lequin et al, 2006 \\
\hline DRS-DI5 & GLWSKIKEAA--------KTAGLMAMGFVNDMV------- & 25 & Batistat et al, 1999 \\
\hline DRS-B5 & GLWNKIKEAA-------SKAAGKAALGFVNEMV------- & 26 & Charpentier et al, 1998 \\
\hline DRS-DI1 & GLWSKIKAAGKEAAKAAAKAAGKAALNAVSEAV------- & 33 & Batistat et al, 1999 \\
\hline DRS-B7 & GLWSNIKTAGKEAAKAALKAAGKAALGAVTDAV------- & 33 & Vouille et al, 1997 \\
\hline DRS-S5 & GLWSKIKTAGKSVAKAAAKAAVKAVTNAV----------- & 29 & Mor and Nicolas, 1994 \\
\hline DRS-S 6 & GLWSKIKTAGKEAAKAAAKAAGKAALNAVSEAI------- & 33 & Chen et al, 2006 \\
\hline DRS-B8 & GLWSKIKEAGKAVL----TAAGKAALGAVSDAV------- & 29 & Vouille et al, 1997 \\
\hline DRS-DA3 & GMWSKIKNAGKAAAKASKKAAGKAALGAVSEAL------- & 33 & Wechselberger, 1998 \\
\hline DRS-DA4 & GMWSKIKNAGKAAK-AAAKAAGKAALGAVSEAM------- & 32 & Auvynet et al, 2009 \\
\hline DRS-B2 & GLWSKIKEVGKEAAKAAAKAAGKAALGAVSEAV------- & 33 & Daly et al, $1992 ;$ Mor et al, 1994 a \\
\hline DRS-01 & GLWSTIKQKGKEAAIAAAKAAGQAALGAL----------- & 29 & Brand et al, 2002 \\
\hline DRS-H6 & GLWSTIKOKGKEAAIAAAKAAGKAVLNAASEAL------- & 33 & Conceição et al, 2006 \\
\hline DRS-H8 & GLWSTIKOKGKEAAIAAAKAAGQAVLNSASEAL------- & 33 & Conceição et al, 2006 \\
\hline DRS-H9 & GLWSTIKQKGKEAAIAAAKAAGQAALNAASEAL------- & 33 & Conceição et al, 2006 \\
\hline DRS-S2 & GLWFTMLKKLGT---MA-LHAGKAALGAAANTISQGTQ-- & 34 & Mor and Nicolas, 1994 \\
\hline DRS-DI 3 & ALWKTMLKKLGT---MA-LHAGKAAFGAAADTISQ----- & 31 & Batistat et al, 1999 \\
\hline DRS-S1 & ALWKTMLKKLGT---MA-LHAGKAALGAAADTISQGTQ-- & 34 & Mor et al, 1991 \\
\hline DRS-S8 & ALWKTMLKKLGT---VA-LHAGKAALGAAADTISQ----- & 31 & Chen et al, 2006 \\
\hline DRS-H5 & ALWKDVLKKIGT---VA-LHAGKAAFGAAADTISQGGS-- & 34 & Conceição et al, 2006 \\
\hline DRS-B1 & AMWKDVLKKIGT---VA-LHAGKAALGAVADTISQ----- & 31 & Charpentier et al, 1998 \\
\hline DRS-TA1 & ALWKDVLKKIGT---VA-LHAGKAALGAVADTISQ----- & 31 & Silva et al, 2000 \\
\hline DRS-A5 & GMWS TIRNVGKSAAKAA-NLPAKAALGAISEAV------- & 32 & Wechselberger, 1998 \\
\hline $\mathrm{DRS}-\mathrm{C} 3$ & SVLSTITDMAK----AA----GRAALNAITGLVNQ----- & 27 & Vanhoye et al, 2003 \\
\hline DRS-A3 & SLWSKIKEMAA----TA----GKAALNAVTGMVNQ----- & 27 & Wechselberger, 1998 \\
\hline DRS-L1 & GLWSKIKEAAK----AA----GKAALNAVTGLVNQGDOPS & 32 & Conlon et al, 2007 \\
\hline DRS-H3 & GLWSTIKNVGKEAAIAA----GKAALGAL----------- & 25 & Brand et al, 2006, \\
\hline DRS-H12 & GLWS TIKNVGKEAAIAA----GKAALGAL----------- & 25 & Thompson et al, 2007 \\
\hline DMS-H4 & GLWSTIKNVGKEAAIAA----GKAALGAL----------- & 25 & Thompson et al, 2007 \\
\hline $\mathrm{DRS}-\mathrm{H} 13$ & GLWSTIKNVGKEAAIAA----GKAVLGSL----------- & 25 & Thompson et al, 2007 \\
\hline DMS-H5 & GLWSTIKNVGKEAAIAA----GKAVLGSL----------- & 25 & Thompson et al, 2007 \\
\hline $\mathrm{DRS}-\mathrm{H} 10$ & GLWSTIKNVAA----AA----GKAALGAL----------- & 21 & Thompson et al, 2007 \\
\hline DMS-H3 & GLWS TIKNVAA----AA----GKAALGAL----------- & 21 & Thompson et al, 2007 \\
\hline DRS-H15 & GLWSKIKDVAA----AA----GKAALGAVNEAL------- & 25 & Thompson et al, 2007 \\
\hline DRS-B9 & ALWKTIIKGAG-------KMIGSLAKNLLGSQAQPES--- & 30 & Fleury et al, 1998 \\
\hline DRS-S11 & ALWKTLLKGAG-------KVFGHVAKQFLGSQGQPES--- & 30 & Lequin et al, 2006 \\
\hline DRS-A4 & GMFTNMLKGIG-------KLAGQAALGAVKTLA------- & 26 & Wechselberger, 1998 \\
\hline DRS-S 3 & ALWKNMLKGIG-------KLAGKAALGAVKKLVGAES--- & 30 & Mor and Nicolas, 1994 \\
\hline DRS-B3 & ALWKNMLKGIG-------KLAGQAALGAVKTLVGAE---- & 29 & Charpentier et al, 1998 \\
\hline DRS-DI 4 & ALWKNMLKGIG-------KLAGQAALGAVKTLVGAES--- & 30 & Batistat et al, 1999 \\
\hline DRS-PH & ALWKEVLKNAG-----------KAALNE INNLV------- & 22 & Huang et al, 2017 \\
\hline DRS-B6 & ALWKDILKNAG-----------KAALNE INQLVNQ----- & 24 & Charpentier et al, 1998 \\
\hline DRS-PS 3 & ALWKDILKNAG-----------KAALNE INQIVQ------ & 23 & Tan et al, 2018 \\
\hline DRS-S4 & ALWMTLLKKVL-------KAAAKAALNAVLVGANA----- & 28 & Mor and Nicolas, 1994 \\
\hline DRS-LI1 & AVWKDFLKNIG-------KAAGKAVLNSVTDMVNE----- & 28 & Marenah et al, 2004 \\
\hline DRS-DA2 & ALWKTLLKKVG-------KVAGKAVLNAVTNMANQNEQ-- & 31 & Wechselberger, 1998 \\
\hline DRS-DI 2 & ALWKTLLKNVG-------KAAGKAALNAVTDMVNQ----- & 28 & Batistat et al, 1999 \\
\hline DRS-PS 4 & ALWKTLLKHVG-------KAAGKAALNAVTDMVNQ----- & 28 & Chen et al, 2019 \\
\hline DRS-DU-1 & ALWKSLLKNVG-------KAAGKAALNAVTDMVNQ----- & 28 & Zhu et al, 2018 \\
\hline DRS-H2 & ALWKSLLKNVG-------VAAGKAALNAVTDMVNQ----- & 28 & Chen et al, 2006 \\
\hline DRS-S7 & GLWKSLLKNVG-------KAAGKAALNAVTDMVNQ----- & 28 & Chen et al, 2003 \\
\hline DRS-H1 & GLWKSLLKNVG-------VAAGKAALNAVTDMVNQ----- & 28 & Chen et al, 2006 \\
\hline DRS-H4 & GLWKSLLKNVG-------VAAGKAALNAVTDMVNQ----- & 28 & Thompson et al, 2007 \\
\hline DRS-B4 & ALWKDILKNVG-------KAAGKAVLNTVTDMVNQ----- & 28 & Charpentier et al, 1998 \\
\hline DRS-CA-1 & ALWKDLLKNVG-------KAAGKAVLNKVTDMVNQ----- & 28 & Zhu et al, 2018 \\
\hline
\end{tabular}

FIGURE 1 | Amino acid sequence alignment of 57 DRS peptides (http://aps.unmc.edu/AP/main.php) using CLUSTAL O (1.2.4) multiple sequence alignment (https://www.ebi.ac.uk/Tools/msa/clustalo/). The letters represent an amino acid according to conventional nomenclature. The dashes are introduced to optimize amino-acids alignments. Blue colors indicate a well-preserved amino acid ( $>55 \%$ of identity), green colors indicate higher rates of preservation within this DRS group (>80\% of identity).

2012a; Zairi et al., 2014), DRS-B2 has been tested in mice and rats in vivo for tumor and antimicrobial activity (NavonVenezia et al, 2002; Huang et al., 2017). Though reportedly administered to humans in non-experimental settings (DRSB's), robust data on pharmacokinetics, efficacy and safety in humans are currently lacking.

\section{RESEARCH IN INFECTIOUS DISEASES}

\section{Antibacterial Activity of Peptides From the DRS Family}

In 1991, Mor was the first to publish on the anti-microbial properties of DRS (Mor et al., 1991). DRS-B1 and S1 show in 
vitro activity against gram positive and negative bacteria with various specificities (Strahilevitz et al., 1994). Derivatives of DRS-S4, DRS-CA1, DRS-DU1 and DRS-PH show in vitro activity against Staphylococcus aureus (including the methicillin resistant strain), Pseudomonas aeruginosa and E. coli, even when they are formed in biofilm (NavonVenezia et al., 2002; Zairi et al., 2014; Liu et al., 2017; Zhu et al., 2018). Though less cytotoxic compared to conventional antibiotics (Zairi et al., 2014), the DRS-S4 derivatives used demonstrated similar or even higher efficacy in vitro(Porat et al., 2006; Rotem et al., 2006; Marynka et al., 2007; Jiang et al., 2014). These results were confirmed in vitro and in vivo with mice infected with $P$. aeruginosa (Navon-Venezia et al., 2002; Marynka et al., 2007) and in various incubation media varying in temperature and acidity (Rydlo et al., 2006). Table 1 provides an overview of the activity of a few DRSs against selected pathogens frequently related to infections and associated with anti-biotic resistance. For a complete list of DRSs and pathogens with corresponding MIC and source, we refer to Supplementary Table 1 s.

\section{Antiviral Activity of Peptides From the DRS Family}

In addition to the antibacterial efficacy, DRS-S1 (and derivatives) show activity against pathogens causing genital infections such as human papilloma virus (HPV) and herpes simplex virus (HSV) (Savoia et al., 2010). Furthermore, modified DRS-S4 has shown antiviral activity against Herpes
Simplex Virus $1 \& 2$, including the acyclovir resistant strain in vitro (Belaid et al., 2002; Bergaoui et al., 2013). For the activity peaks in case of DRS administration prior to incubation with the virus, interference early in the viral replication cycle is hypothesized (Belaid et al., 2002; Mechlia et al., 2018). DRSS4 and S9 both demonstrate in vitro activity against HIV-1 virus (Lorin et al., 2005; Wang et al., 2010) by inhibition of HIV attachment to endometrial cells, uptake by the dendritic cells and subsequent transmission to T-cells (Lorin et al., 2005). Again, interference of DRS-S4 in an early phase of virus replication is suggested as less reduction of HIV is observed once the T-cells have been infected. Substitution of methionine for lysine on the 4th position DRS-S4 to reduce cytotoxicity to mammalian cells, did not affect the anti-HIV activity observed (Lorin et al., 2005). More recently, DRS-S4 has shown effectivity against Rabies virus in mice (Mechlia et al., 2018).

\section{Antifungal Activity of Peptides From the DRS Family}

DRSs also show activity against fungi in vitro. So far, DRS-B1-B2, DRS-S1-S5 DRS-O1, DRS-CA1 DRS-DU1 all demonstrate cytotoxicity against Candida albicans (Strahilevitz et al., 1994; Mor et al., 1994a; Mor et al., 1994b; Leite et al., 2008; Nicolas and El Amri, 2009; Shi et al., 2016; Huang et al., 2017; Zhu et al., 2018). In particular, DRS-S3 shows anti-fungal activity by means of triggering apoptosis (Morton et al., 2007). In Aspergillus fumigates, cytotoxic activity was demonstrated for DRS-B1-B2 and DRS-S1, but not DRS-S5. Minimal inhibitory

TABLE 1 | Effectivity of Dermaseptins in vitro against various pathogens.

\begin{tabular}{|c|c|c|c|c|c|c|c|}
\hline & E. coli & E. faecalis & $P$. aeruginosa & S. aureus & C. albicans & A. fumigatus & $\begin{array}{l}\text { Human } \\
\text { erythrocytes }\end{array}$ \\
\hline \multicolumn{8}{|l|}{ DRS-B1 } \\
\hline \multicolumn{8}{|l|}{ DRS-B2 } \\
\hline \multicolumn{8}{|l|}{ DRS-B3 } \\
\hline \multicolumn{8}{|l|}{ DRS-B4 } \\
\hline \multicolumn{8}{|l|}{ DRS-S1 } \\
\hline \multicolumn{8}{|l|}{ DRS-S2 } \\
\hline \multicolumn{8}{|l|}{ DRS-S3 } \\
\hline \multicolumn{8}{|c|}{ DRS-S4 } \\
\hline \multicolumn{8}{|c|}{ DRS-S4 K4-S4(1-16) } \\
\hline \multicolumn{8}{|c|}{ DRS-S5 } \\
\hline \multicolumn{8}{|l|}{ DRS-PH } \\
\hline \multicolumn{8}{|l|}{ DRS-H3 } \\
\hline \multicolumn{8}{|l|}{ DRS-L1 } \\
\hline \multicolumn{8}{|l|}{ DRS-O1 } \\
\hline \multicolumn{8}{|l|}{ DRS-DI06 } \\
\hline \multicolumn{8}{|l|}{ DRS-CA1 } \\
\hline \multicolumn{8}{|l|}{ DRS-DU1 } \\
\hline \multicolumn{8}{|l|}{ DRS-PD1 } \\
\hline \multicolumn{8}{|l|}{ DRS-PD2 } \\
\hline DRS-PS4 & & & & & & & \\
\hline
\end{tabular}

This table gives an overview of the effectivity of DRS activity against a selected number of pathogens. Cells are colored dark green if: more than one study agrees on high activity (MIC <10 $\mu \mathrm{M}$ ); light green if: 1 study finds high activity (MIC <10 $\mathrm{MM}$ ); orange if studies do not agree on MIC; red if one or more studies agree on low activity (MIC > $10 \mu \mathrm{M})$; white indicates that there was no published data available. In the Human erythrocyte column, the opposite is instinctively true; green color indicates low, and red indicates high activity (Strahilevitz et al., 1994; Mor et al., 1994a; Mor et al., 1994b; Carpentier et al., 1998; Brand et al., 2002; Navon-Venezia et al., 2002; Conceicao et al., 2006; Brand et al., 2006; Conlon et al., 2007; Galanth et al., 2009; Zairi et al., 2014; Huang et al., 2017; Nicolas and El Amri, 2009; Leite et al., 2008; Jiang et al., 2014; De Assis et al., 2016; Shi et al., 2016; Belmadani et al., 2018; Zhu et al., 2018; Shams et al., 2019) for more information, see Supplementary Table S1. 
concentrations (MIC) ranging from $3.1 \mu \mathrm{M}$ to $30 \mu \mathrm{M}$ were observed. In addition, others (Belmadani et al., 2018) found that DRS-S1 inhibits C. albicans in biofilm formation when using concentrations of $100 \mu \mathrm{M}$. These findings are summarized in Table 1.

\section{Antiparasitic Activity of Peptides From the DRS Family}

Finally, DRS-S3 and S4 derivatives appear able to target malarial parasites within a host erythrocyte without disrupting the host (Ghosh et al., 1997; Krugliak et al., 2000; Dagan et al., 2002). In addition DRS from the Phyllomedusa oreades (DRS-O1) has shown activity against Schistosoma mansoni (de Moraes et al., 2011), Trypanosoma cruzi (Brand et al., 2002; Leite et al., 2005) and Leishmania amazonesis (Brand et al., 2006).

\section{RESEARCH IN ONCOLOGY}

Parallel to the efficacy against microbials, efficacy against tumor cells has been studied as well (Hoskin and Ramamoorthy, 2008; Balandin et al., 2016). Table 2 summarizes the data published on the impact of DRS on selected cancer cell lines.

DRS-B2 for example, shows a dose dependent growth inhibition of prostatic adenocarcinomas $(\mathrm{GI} 50=0.71-2.65 \mu \mathrm{M})$ and some pancreatic cancer cell lines. Administration of $1 \mu \mathrm{M}$ DRS-B2 was enough for 50\% reduction in colony formation in both prostate adenoma and mammary carcinoma cell lines (van Zoggel et al., 2012). No growth inhibition on glioblastoma and mammary carcinoma cell lines was observed (van Zoggel et al., 2012; Dos Santos et al., 2017). At a concentration of $15 \mu \mathrm{M}$, no activity against stromal prostate fibroblasts and skin fibroblasts was observed, indicating low cytotoxicity in surrounding tissue (van Zoggel et al., 2012; Dos Santos et al., 2017). In vivo, DRS did not arrest human PC3 tumor growth in mice, but inhibited growth with more than $50 \%$ vs. controls attributed to a $24 \%$ reduction of angiogenesis in tumors of treatment groups, quantified by CD34+ positive stained endothelial cells. No side-effects or differences in total blood count were observed (van Zoggel et al., 2012).

Furthermore, DRS-PH shows IC50's of $0.69 \mu \mathrm{M}, 2.01 \mu \mathrm{M}$, and $2.36 \mu \mathrm{M}$, against breast cancer adenoma (MCF-7), non-small cell lung carcinoma (NSCLC) (H157), and glioblastoma (U251MG) in vitro respectively (Huang et al., 2017). For DRS-PH less efficacy was observed against PC3 cell lines, compared to the activity profile of DRS-B2. DRS-PH did also show some cytotoxicity against human dermal endothelium, and mammalian red blood cells (Huang et al., 2017).

\section{MECHANISM OF ACTION}

The mode of action by which antimicrobial peptides kill microbes is mainly known for $\alpha$-helix cationic peptides which have been extensively studied (Amiche and Galanth, 2011; Melo and Castanho, 2012; Bahar and Ren, 2013). Two models explaining the interaction of $\alpha$-helical cationic AMPs with membranes have been proposed: the barrel-stave model (Ehrenstein and Lecar, 1977) and the carpet or carpet model (Pouny et al, 1992), both taken over by Shai in 1999 (Shai, 1999). The cationic antimicrobial peptides, destructured in aqueous media, adopt an $\alpha$-helical structure in contact with the plasma membranes of the host cell and then interact with the negative charges of the components of the membrane surface (Zasloff, 2002). After binding, the peptide will disrupt the permeability of the membrane and either cause the death of the microorganism or enter the cell compartment and interact with intracellular targets. Note that most cationic antimicrobial peptides have a direct action on the membrane of bacteria, but some such as buforine II act intracellularly (Park et al, 1998). In most of the mechanisms described, the binding of antimicrobial peptide to the membrane is followed by permeabilization of the membrane, which alone can cause cell death, or as a step in more complex processes.

In addition, very few studies on the anti-tumour action mechanism(s) of antimicrobial peptides have been conducted. The most important results show that their oncolytic mechanisms include: (i) induction of necrosis via cell membrane lysis, (ii)

TABLE 2 | Overview of the activity DRSs against various cancer cell types.

\begin{tabular}{|c|c|c|c|c|c|c|c|}
\hline & HEPG2 & MCF-7 & U251MG & H157 & MDA-MB-435S & PC-3 & $\begin{array}{l}\text { Human } \\
\text { erythrocytes }\end{array}$ \\
\hline \multirow{2}{*}{\multicolumn{8}{|c|}{$\begin{array}{l}\text { DRS-B2 } \\
\text { DRS-B3 }\end{array}$}} \\
\hline & & & & & & & \\
\hline \multicolumn{8}{|l|}{ DRS-B4 } \\
\hline \multicolumn{8}{|l|}{ DRS-PH } \\
\hline \multicolumn{8}{|l|}{ DRS-L1 } \\
\hline \multicolumn{8}{|l|}{ DRS-CA1 } \\
\hline \multicolumn{8}{|l|}{ DRS-DU1 } \\
\hline \multicolumn{8}{|l|}{ DRS-PD1 } \\
\hline \multicolumn{8}{|l|}{ DRS-PD2 } \\
\hline DRS-PS4 & & & & & & & \\
\hline
\end{tabular}

This table gives an overview of the DRS that have been tested for activity against some human cancer cell lines in vitro. Cells are colored in green if: high activity (<10 $\mu \mathrm{M}$ to reach EC50) was found, orange if: two studies did not agree on high activity, red if they agreed on low activity (> $10 \mu \mathrm{M}$ to reach EC50), white if: no published data was available. In the Human erythrocyte column, the opposite is instinctively true; green color indicates low, and red indicates high activity (van Zoggel et al., 2012; Dos Santos et al., 2017; Mor et al., 1994b; Nicolas and El Amri, 2009; Charpentier et al., 1998; Conlon et al., 2007; Galanth et al., 2009; Shi et al., 2016; Huang et al., 2017; Zhu et al., 2018) 
initiation of apoptosis via mitochondrial membrane rupture and (iii) non-membranolytic modes of action (Ellerby et al., 1999; Chen et al., 2001; Deslouches and Di, 2017).

Below, we will elaborate on how DRSs disrupt the lipid bilayer of microbes and cancer cells, and which features are possibly responsible for DRSs affinity to microbes and cancer cells. Additionally, we will discuss how DRSs modulate host immune systems and pathogen's gene expression. Last, we summarize the evidence of DRS acting as a receptor (ant)agonist.

\section{Disruption of the Lipid Bilayer}

One common feature DRSs often demonstrate is their disruption of the lipid bilayer of a target cell. Early evidence for this is the depolarization of bacterial membranes in vitro (Fleury and Longeron, 1998). To do this, DRSs likely form tetramers in their quaternary structure that form toroidal pores. Using the planar lipid bilayer technique, it was shown that the DRS peptides accumulate in a carpet like manner on the outside of a lipid bilayer until a threshold concentration is reached, causing them to form pores in which the peptides are intercalated with the phospholipid headgroups of the membrane (Duclohier, 2006). The selectivity of these pores appears to be determined by the phospholipid headgroups of the plasma membrane. The carpet of DRSs on the outside of the lipid bilayer as well as tetramer channel with intercalated phospholipid headgroups causes the membrane to lose its integrity (Yeaman and Yount, 2003). The reason why DRS favor binding to some pathogens and tumors is still under investigation and several hypotheses exist, discussed here are the possible influence of; membrane charge, membrane sulfatation and membrane fluidity.

First DRSs are generally rather cationic peptides and thus more prone to bind negatively charged membranes. Bacteria and cancer cell membranes typically have a net negative charge, the former due to negatively charged phospholipids on inner (gram negative) and single (gram positive) membranes (Shai, 2002), the latter due to expression of phosphatidylserine and negatively charged mucin proteins (Utsugi et al., 1991; Hoskin and Ramamoorthy, 2008). Interestingly, erythrocytes have net negatively charged membranes as well, but are generally less affected by DRS (Caillon et al., 2013).

Second the sulfatation of glycosaminoglycans (GAG)'s on the membrane surface seems to be of high importance for DRS-B2's effectivity against prostate cancer cell lines (PC3) (Dos Santos et al., 2017). Low concentrations of Chondroitin Sulfate C (CSC), which is a sulfated GAG, contribute to the a-helical shape of DRS-B2, which is its biological active form. Interestingly, sulfated GAG's seem to be essential to the effectivity of cell penetrating peptides (CPPs) as well (Yang et al., 2014). Furthermore, when Zhu et al. (2018) investigated the activity of DRS-DP1 and 2, they found that by introducing a TAT (GRKKRRQRRR) peptide at the N-terminal, affinity to the cell membrane and interaction with GAG's increased.

Third, cancer cells often have increased membrane fluidity and irregularities of cell surface which contributes to membrane destabilization and could affect receptor binding and other communications between cancer cell and environment (Hoskin and Ramamoorthy, 2008). This may account for DRSs being more effective against one cancer type (PC3) than another (Leuschner and Hansel, 2004; van Zoggel et al., 2012a). It has been observed that membrane environment with a strong positive curvature strain influences the DRS-B2 into a state that facilitates insertion into the membrane (Galanth et al., 2009).

\section{Modulation of the Host Immune System}

Besides the membrane disrupting activity, DRS likely modulates the host defense system as well. By introducing DRS-S1, neutrophils of rat and humans stimulate their microbicidal activities such as their production of reactive oxygen species (Ammar et al., 1998). Moreover, DRS-S9 is chemotactic for human leukocytes (Auvynet et al., 2008). On the other hand, DRS-S4 has been observed to bind Lipopolysaccharides (LPS), which would rather suppress activation of macrophages and decrease the production of inflammatory cytokines (NavonVenezia et al., 2002). Furthermore, DRS also shows angiostatic activities, which may influence tumor growth (van Zoggel et al., 2010; van Zoggel et al., 2012).

\section{Modulation of the Pathogen's Gene Expression}

We previously mentioned that DRSs can permeate membranes of different types of cells and cell nuclei, however it is also possible that DRS changes gene expression in a pathogen cell as well. DRS-S1 Modulates the expression of C. albicans genes, such as the Hyphal wall protein 1 (HWP1) gene (Belmadani et al., 2018). In vitro, its expression was downregulated which likely accounts for the modified cell morphology that was found. Furthermore, changes in aspartic protease genes were found.

\section{Interaction With Cell Membrane Receptors}

Lastly, it seems unlikely that there is a partner protein on the surface or cytoplasm of the tumor cells that can account for the effects of DRS. This is illustrated by the example in which DRSB2's activity on PC3 cell lines is almost identical when composed of only amino acids in D configuration, (Dos Santos et al., 2017). Since receptors are usually stereo-selective, it is unlikely DRS-B2 works through a receptor. However, there is evidence that some DRS can inhibit adenosine triphosphate (ATP) production through receptor binding (Laughlin and Ahmad, 2010).

\section{FUTURE PERSPECTIVES}

As DRSs act against a wide variety of pathogens and tumor cell lines, it is tempting to speculate on their therapeutic potential. Nevertheless, current knowledge on DRS is fragmented with respect to mechanism of action and diverse with respect to pathogens and cancer cell lines studied. Consecutively, we will discuss remaining questions on the mechanism of action, potential clinical applications and safety. 


\section{Future Research on Available DRSs}

For research on DRSs to move forward on the already investigated DRSs described in this paper, it is essential to understand the mechanism of action of a specific DRS against a pathogen to finetune this DRS into a molecule that can target a specific clinical problem. These potential clinical therapies include treatment of infections caused by specific micro-organisms, the treatment of infections caused by multiple micro-organisms such as skin infections, and as a component of cancer treatment. Furthermore, we discuss the current use of DRS in biotechnology.

It seems likely that the mode of action of DRSs relies, similarly to many AMPs, in part on membrane disruption of target cells. Important factors in this include the cationic nature of the peptide, and its ability to retain an $\alpha$-helical shape. The presence of certain phospholipids, GAGs, and proteins contribute to this. However, the means to identify more of the cell membrane factors, including the shape and fluidity of the cell membrane are not readily available, and would require innovative tools and techniques at the interface of chemistry biology and biophysics.

DRSs can be tested for specific clinical problems in vivo. For example, some DRSs act against specific, anti-biotic resistant pathogens. From Table 1 we can infer that DRSB4, DRS-O1, DRS-DI06, DRS-CA1, DRS-DU1, DRS-PD2 and DRS-PS4 are all promising candidates for specifically targeting $P$. aeruginosa, a pan-resistant bacterium notorious for causing severe infections in hospital settings. Another example is DRS-O1 which has thus far been the only DRS to show activity against the $S$. mansoni, a neglected tropical disease in need of treatment possibilities.

On the other hand, there are some DRSs that can act against a range of pathogens. This makes some DRSs ideal for clinical applications in which several pathogens need to be targeted. Skin infections, for example in diabetic foot ulcers or catheter infections are caused by organisms such as gram-positive bacteria as well as some fungi (Schittek et al., 2008). From Table 1 we can conclude that DRS-S3, DRS-S5, DRS-CA1, DRS-DU1, DRS-PS4, DRS-PD2 and DRS-O1 all show activity against the $S$. aureus (some including the methicillin resistant variant), as well as the C. albicans fungus, without damaging erythrocytes. Gomes and colleagues (2015) have already positively assessed DRS's incorporation in cotton gauzes and show potential in fast-release medical applications. Therefore they are potential starting points for therapeutic applications in skin infections.

Some even speculate that there is potential for DRS as a contraceptive, as DRS-S4 is spermicidal (Zairi et al., 2005). DRS-S4 shows activity against HIV, and several other genital pathogens (Lorin et al., 2005; Savoia et al., 2010). However, it appears the recent literature prefers antimicrobials that are within (or close to) the human genome for the use as contraceptives (Tanphaichitr et al., 2016). Moreover, the clinical relevance of such a contraceptive as well as the high degree of effectivity that would be demanded are questionable.

There is the potential of DRS as an aiding therapeutic in cancer treatment by working in tandem with conventional chemotherapies. This idea finds its roots in a hypothesis regarding the evolutionary origins of DRSs in frogs. The idea is that DRSs function as an accessory protein that lyses cells and penetrates tissue to allow effectiveness of other neuromodulators and enzymes in frog secretions (Konig et al., 2015). This contrasts with the view that DRSs are part of an innate immune system. Indeed, there is striking similarity in the amino acid sequences of preproDRS and precursors of demorphin and deltorphin (Amiche et al., 1994) (which are powerful opioid agonists), suggesting these peptides work together to achieve a common goal. This idea might extend to clinical practice as well. Potentially DRS could be part of a drug delivery system and play similar role to other cell penetrating peptides in cancer research (Bolhassani, 2011; Bolhassani et al., 2011; Yang et al., 2014). DRS would penetrate and disintegrate cell membranes of specific cancer cells and (attached) conventional cytostatic agents may then - more effectively - affect the tumor tissue. Some support for this idea comes from a study using Cecropin A and conventional chemotherapy on leukemic patients, Cecropin A increased the effect of the conventional therapy (Hui et al., 2002). Possibly the same idea can be used when targeting microbial pathogens (Balaban et al., 2004). Potentially, red blood cells or chitosan nanoparticles could function as a potential carrier for DRS (Feder et al., 2001; Medeiros et al., 2014).

Meanwhile the field of applied biotechnology has moved forward on these developments and researchers have incorporated DRS in the genetic material of potato and citrus plants. The plants can express these peptides and protect the crops from disease (Rivero et al., 2012; Furman et al., 2013). More recently, DRS-B1 was modified (N-terminally modified and recombined respectively) to protect poplar plants and tobacco plants from infections by inserting the DRS protein in the genome of the host (Yevtushenko and Misra, 2019; Shams et al., 2019). On the one hand pesticides can now be avoided on these crops, on the other hand studies already report resistance of bacteria to anti-microbial peptides by producing positively charged molecules on the membrane and pumping AMP's out of the cells (Joo, Fu \& Otto, 2016; Andersson Hughes \& Kubicek Sutherland, 2016). Genetically altering plants on a large scale could potentially endanger DRS's use as an antibiotic in humans.

Lastly, the safety of DRS in humans remains to be investigated. Even though several DRS have been administered to mice and rats, to our knowledge, no phase-1 clinical trials have been conducted on the safety of any DRS in humans thus far. Encouragingly, many of the documented short-term adverse effects of the Kambo ritual such as nausea and tachycardia can be ascribed to other molecules in the cocktail (Erspamer et al., 1993), nevertheless the safety of the DRS remain to be shown. Researchers in many fields could benefit from the knowledge of a safe DRS peptide.

\section{Future Research on Novel DRSs}

The investigation of other Anuran species is likely to yield anti-microbial or DRS like peptides that can contribute to illuminating the mechanism of action of these peptides and 
provide starting points for therapeutical treatments. According to some estimations, skin compounds have been detected and isolated from 400 anuran species, which means that more than $90 \%$ of all documented frog species still await screening (Konig et al., 2015). The isolated peptides from different species thus far are very often unique and sometimes useful which makes it very likely that new, useful and novel biomolecules await discovery.

To ensure these new molecules contribute to scientific literature in a less fragmented way, it is important to identify the questions that remain on the mechanism of action of DRS. Whenever a new DRS or a modification is tested, ideally these mechanisms should be evaluated: 1) disruption of plasma/mitochondrial membranes; 2) necrosis; 3) apoptosis; 4) mechanisms of mediated immunity; 5) membrane receptor involvement; 6) inhibition of DNA synthesis; 7) anti-angiogenic effects (Gaspar et al., 2013). Additionally, their activity against human erythrocytes and epithelial cells should be evaluated to assess clinical relevance and help understand how DRS recognize target cells.

\section{REFERENCES}

Alves, R. R., and Alves, H. N. (2011). The faunal drugstore: animal-based remedies used in traditional medicines in Latin America. J. Ethnobiol. Ethnomed. 7, 9. doi: 10.1186/1746-4269-7-9

Amiche, M., and Galanth, C. (2011). Dermaseptins as Models for the Elucidation of Membrane-Acting Helical Amphipathic Antimicrobial Peptides. Curr. Pharmaceutical. Biotechnol. 12, 1184-1193. doi: 10.2174/138920111796117319

Amiche, M., Ducancel, F., Mor, A., Boulain, J. C., Menez, A., and Nicolas, P. (1994). Precursors of vertebrate peptide antibiotics dermaseptin b and adenoregulin have extensive sequence identities with precursors of opioid peptides dermorphin, dermenkephalin, and deltorphins. J. Biol. Chem. 269 (27), 17847-17852.

Amiche, M., Ladram, A., and Nicolas, P. (2008). A consistent nomenclature of antimicrobial peptides isolated from frogs of the subfamily Phyllomedusinae. Peptides 29 (11), 2074-2082. doi: 10.1016/j.peptides.2008.06.017

Ammar, B., Perianin, A., Mor, A., Sarfati, G., Tissot, M., Nicolas, P., et al. (1998). Dermaseptin, a peptide antibiotic, stimulates microbicidal activities of polymorphonuclear leukocytes. Biochem. Biophys. Res. Commun. 247 (3), 870875. doi: 10.1006/bbrc.1998.8879

Andersson, D. I., Hughes, D., and Kubicek-Sutherland, J. Z. (2016). Mechanisms and consequences of bacterial resistance to antimicrobial peptides. Drug Resist. Updates 26, 43-57. doi: 10.1016/j.drup.2016.04.002

Aquila, I., Gratteri, S., Sacco, M. A., Fineschi, V., Magi, S., Castaldo, P., et al. (2018). The Biological Effects of Kambo: Is there a relationship between its administration and sudden death? J. Forensic Sci. 63 (3), 965-968. doi: 10.1111/1556-4029.13641

Auvynet, C., El Amri, C., Lacombe, C., Bruston, F., Bourdais, J., Nicolas, P., et al. (2008). Structural requirements for antimicrobial versus chemoattractant activities for dermaseptin S9. FEBS J. 275 (16), 4134-4151. doi: 10.1111/j.1742-4658.2008.06554.x

Bahar, A. A., and Ren, D. (2013). Antimicrobial peptides. Pharmaceuticals 6, 1543-1575. doi: 10.3390/ph6121543

Balaban, N., Gov, Y., Giacometti, A., Cirioni, O., Ghiselli, R., Mocchegiani, F., et al. (2004). A chimeric peptide composed of a dermaseptin derivative and an RNA III-inhibiting peptide prevents graft-associated infections by antibioticresistant staphylococci. Antimicrob. Agents Chemother. 48 (7), 2544-2550. doi: 10.1128/AAC.48.7.2544-2550.2004

Balandin, S., Emelianova, A., Kalashnikova, M., Kokryakov, V., Shamova, O., and Ovchinnikova, T. (2016). Molecular mechanisms of antitumor effect of natural
DRS are a complex family of bioactive peptides. Accumulating evidence suggests their efficacy in a wide variety of medical applications. Despite the still puzzling mechanisms of action, DRSs are extremely suitable for specific medical problems.

\section{AUTHOR CONTRIBUTIONS}

EB is first author and writer of this manuscript. DD supervised the initial draft of this manuscript, helped identify the aims and research question and came up with the initial structure. MA critically reviewed the drafts several times, elaborated on the mechanisms of action, revised structure and added figures.

\section{SUPPLEMENTARY MATERIAL}

The Supplementary Material for this article can be found online at: https://www.frontiersin.org/articles/10.3389/fphar.2019.01421/ full\#supplementary-material antimicrobial peptides. Russian J. Bioorg. Chem. 42 (6), 575-589. doi: 10.1134/ S1068162016060029

Batista, C. V., da Silva, L. R., Sebben, A., Scaloni, A., Ferrara, L., Paiva, G. R., et al. (1999). Antimicrobial peptides from the Brazilian frog Phyllomedusa distincta. Peptides 20, 679-686. doi: 10.1016/s0196-9781(99)00050-9

Belaid, A., Aouni, M., Khelifa, R., Trabelsi, A., Jemmali, M., and Hani, K. (2002). In vitro antiviral activity of dermaseptins against herpes simplex virus type 1. J. Med. Virol. 66 (2), 229-234. doi: 10.1002/jmv.2134

Belmadani, A., Semlali, A., and Rouabhia, M. (2018). Dermaseptin-S1 decreases Candida albicans growth, biofilm formation and the expression of hyphal wall protein 1 and aspartic protease genes. J. Appl. Microbiol. 125 (1), 72-83. doi: 10.1111/jam.13745

Bergaoui, I., Zairi, A., Tangy, F., Aouni, M., Selmi, B., and Hani, K. (2013). In vitro antiviral activity of dermaseptin S(4) and derivatives from amphibian skin against herpes simplex virus type 2. J. Med. Virol. 85 (2), 272-281. doi: 10.1002/ jmv. 23450

Bisset, N. G. (1991). One man's poison, another man's medicine? J. Ethnopharmacol. 32 (1-3), 71-81. doi: 10.1016/0378-8741(91)90105-m

Bolhassani, A., Safaiyan, S., and Rafati, S. (2011). Improvement of different vaccine delivery systems for cancer therapy. Mol. Cancer 10, 3. doi: 10.1186/1476-4598-10-3

Bolhassani, A. (2011). Potential efficacy of cell-penetrating peptides for nucleic acid and drug delivery in cancer. Biochim. Biophys. Acta 1816 (2), 232-246. doi: 10.1016/j.bbcan.2011.07.006

Brand, G. D., Leite, J. R., Silva, L. P., Albuquerque, S., Prates, M. V., Azevedo, R. B., et al. (2002). Dermaseptins from Phyllomedusa oreades and Phyllomedusa distincta. Anti-Trypanosoma cruzi activity without cytotoxicity to mammalian cells. J. Biol. Chem. 277 (51), 49332-49340. doi: 10.1074/jbc.M209289200

Brand, G. D., Leite, J. R., de Sa Mandel, S. M., Mesquita, D. A., Silva, L. P., Prates, M. V., et al. (2006). Novel dermaseptins from Phyllomedusa hypochondrialis (Amphibia). Biochem. Biophys. Res. Commun. 347 (3), 739-746. doi: 10.1016/j. bbrc.2006.06.168

Caillon, L., Killian, J. A., Lequin, O., and Khemtemourian, L. (2013). Biophysical investigation of the membrane-disrupting mechanism of the antimicrobial and amyloid-like peptide dermaseptin S9. PloS One 8 (10), e75528. doi: 10.1371/ journal.pone.0075528

Charpentier, S., Amiche, M., Mester, J., Vouille, V., Le Caer, J. P., Nicolas, P., et al. (1998). Structure, synthesis, and molecular cloning of dermaseptins B, a family of skin peptide antibiotics. J. Biol. Chem. 273 (24), 14690-14697. doi: 10.1074/ jbc.273.24.14690 
Chen, Y., Xu, X., Hong, S., Chen, J., Liu, N., Underhill, C., et al. (2001). RGDTachyplesin inhibits tumor growth. Cancer Res. 61, 2434-2438.

Chen, T., Tang, L., and Shaw, C. (2003). Identification of three novel Phyllomedusa sauvagei dermaseptins (sVI-sVIII) by cloning from a skin secretion-derived cDNA library. Regul. Pept. 116, 139-146. doi: 10.1016/j.regpep.2003.08.001

Chen, T., Zhou, M., Gagliardo, R., Walker, B., and Shaw, C. (2006). Elements of the granular gland peptidome and transcriptome persist in air-dried skin of the South American orange-legged leaf frog, Phyllomedusa hypocondrialis. Peptides 27, 2129-2136. doi: 10.1016/j.peptides.2006.04.006

Chen, D., Zhou, X., Chen, X., Huang, L., Xi, X., Ma, C., et al. (2019). Evaluating the bioactivity of a novel antimicrobial and anticancer peptide, dermaseptinps4(der-ps4), from the skin secretion of Phyllomedusa sauvagii. Molecules 24 (16), E2974. doi: 10.3390/molecules 24162974

Colak, S., and Medema, J. P. (2014). Cancer stem cells-important players in tumor therapy resistance. FEBS J. 281 (21), 4779-4791. doi: 10.1111/febs.13023

Conceicao, K., Konno, K., Richardson, M., Antoniazzi, M. M., Jared, C., Daffre, S., et al. (2006). Isolation and biochemical characterization of peptides presenting antimicrobial activity from the skin of Phyllomedusa hypochondrialis. Peptides 27 (12), 3092-3099. doi: 10.1016/j.peptides.2006.08.005

Conlon, J. M., Woodhams, D. C., Raza, H., Coquet, L., Leprince, J., Jouenne, T., et al. (2007). Peptides with differential cytolytic activity from skin secretions of the lemur leaf frog Hylomantis lemur (Hylidae: Phyllomedusinae). Toxicon 50 (4), 498-506. doi: 10.1016/j.toxicon.2007.04.017

Corrie, P. G. (2008). Cytotoxic chemotherapy: clinical aspects. Medicine 36 (1), 24-28. doi: 10.1016/j.mpmed.2007.10.012

Dagan, A., Efron, L., Gaidukov, L., Mor, A., and Ginsburg, H. (2002). In vitro antiplasmodium effects of dermaseptin S4 derivatives. Antimicrob. Agents Chemother. 46 (4), 1059-1066. doi: 10.1128/aac.46.4.1059-1066.2002

Daly, J. W., Caceres, J., Moni, R. W., Gusovsky, F., Moos, M., Seamon, K. B., et al. (1992). Frog secretions and hunting magic in the upper Amazon: identification of a peptide that interacts with an adenosine receptor. Proc. Natl. Acad. Sci. U. S. A. 89 (22), 10960-10963. doi: 10.1073/pnas.89.22.10960

De Assis, A. B., Dos Santos, C., Dutra, F. P., de Oliveira Motta, A., Costa, F. S., Navas, C. A., et al. (2016). Assessing antibacterial potential of components of Phyllomedusa distincta skin and its associated dermal microbiota. J. Chem. Ecol. 42 (2), 139-148. doi: 10.1007/s10886-016-0665-3

De Lima E.C., and Labate B.C. (2008). A expansão urbana do kampo (Phyllomedusa bicolor): notas etnográficas1. DroDrogas e Cultura: Novas Perspectivas. pp. 315-344.

de Moraes, J., Nascimento, C., Miura, L. M., Leite, J. R., Nakano, E., and Kawano, T. (2011). Evaluation of the in vitro activity of dermaseptin 01, a cationic antimicrobial peptide, against Schistosoma mansoni. Chem. Biodivers. 8 (3), 548-558. doi: 10.1002/cbdv.201000163

Deslouches, B., and Di, Y. P. (2017). Antimicrobial peptides with selective antitumor mechanisms: prospect for anticancer applications. Oncotarget. 8 (28), 46635-46651. doi: 10.18632/oncotarget.16743

Dias, D. A., Urban, S., and Roessner, U. (2012). A historical overview of natural products in drug discovery. Metabolites 2 (2), 303-336. doi: 10.3390/metabo2020303

Dos Santos, C., Hamadat, S., Le Saux, K., Newton, C., Mazouni, M., Zargarian, L., et al. (2017). Studies of the antitumor mechanism of action of dermaseptin B2, a multifunctional cationic antimicrobial peptide, reveal a partial implication of cell surface glycosaminoglycans. PloS One 12 (8), e0182926. doi: 10.1371/ journal.pone.0182926

Duclohier, H. (2006). Bilayer lipid composition modulates the activity of dermaseptins, polycationic antimicrobial peptides. Eur. Biophys. J. 35 (5), 401409. doi: 10.1007/s00249-006-0047-9

Ehrenstein, G., and Lecar, H. (1977). Electrically gated ionic channels in lipid bilayers. Q. Rev. Biophys. 10, 1-34. doi: 10.1017/s0033583500000123

Ellerby, H. M., Arap, W., Ellerby, L. M., Kain, R., Andrusiak, R., Rio, G. D., et al. (1999). Anti-cancer activity of targeted proapoptotic peptides. Nat. Med. 5, 1032-1038. doi: 10.1038/12469

Erspamer, V., Melchiorri, P., Broccardo, M., Erspamer, G. F., Falaschi, P., Improta, G., et al. (1981). The brain-gut-skin triangle: new peptides. Peptides 2, 7-16. doi: 10.1016/0196-9781(81)90003-6

Erspamer, V., Erspamer, G. F., Severini, C., Potenza, R. L., Barra, D., Mignogna, G., et al. (1993). Pharmacological studies of 'sapo' from the frog Phyllomedusa bicolor skin: a drug used by the Peruvian Matses Indians in shamanic hunting practices. Toxicon 31 (9), 1099-1111. doi: 10.1016/00410101(93)90125-3
Feder, R., Nehushtai, R., and Mor, A. (2001). Affinity driven molecular transfer from erythrocyte membrane to target cells. Peptides 22 (10), 1683-1690. doi: 10.1016/s0196-9781(01)00504-6

Fleury, M., and Longeron, D. (1998). Combined resistivity and capillary pressure measurements using micropore membrane technique. J. Pet. Sci. Eng. 19 (1-2), 73-79.

Fleury, Y., Vouille, V., Beven, L., Amiche, M., Wróblewski, H., Delfour, A., et al. (1998). Synthesis, antimicrobial activity and gene structure of a novel member of the dermaseptin B family, Biochim. Biophys. Acta 1396, 228-236. doi: 10.1016/s0167-4781(97)00194-2

Furman, N., Kobayashi, K., Zanek, M. C., Calcagno, J., Garcia, M. L., and Mentaberry, A. (2013). Transgenic sweet orange plants expressing a dermaseptin coding sequence show reduced symptoms of citrus canker disease. J. Biotechnol. 167 (4), 412-419. doi: 10.1016/j.jbiotec.2013.07.019

Galanth, C., Abbassi, F., Lequin, O., Ayala-Sanmartin, J., Ladram, A., Nicolas, P., et al. (2009). Mechanism of antibacterial action of dermaseptin B2: interplay between helix-hinge-helix structure and membrane curvature strain. Biochemistry 48 (2), 313-327. doi: 10.1021/bi802025a

Gaspar, D., Veiga, A. S., and Castanho, M. A. (2013). From antimicrobial to anticancer peptides. a review. Front. Microbiol. 4, 294. doi: 10.3389/fmicb.2013.00294

Ghosh, J. K., Shaool, D., Guillaud, P., Ciceron, L., Mazier, D., Kustanovich, I., et al. (1997). Selective cytotoxicity of dermaseptin S3 toward intraerythrocytic Plasmodium falciparum and the underlying molecular basis. J. Biol. Chem. 272 (50), 31609-31616. doi: 10.1074/jbc.272.50.31609

Gomes, A. P., Mano, J. F., Queiroz, J. A., and Gouveia, I. C. (2015). Incorporation of antimicrobial peptides on functionalized cotton gauzes for medical applications. Carbohydr. Polym. 127, 451-461. doi: 10.1016/j.carbpol.2015.03.089

Gorman, P. (2015). Sapo in my soul (Gorman Bench Press).

Hesselink, J. M. K. (2018). Kambô: A Shamanic Medicine-Personal Testimonies. JOJ Case Stud. 8 (3), 555739. doi: 10.19080/JOJCS.2018.08.555739

Hoskin, D. W., and Ramamoorthy, A. (2008). Studies on anticancer activities of antimicrobial peptides. Biochim. Biophys. Acta 1778 (2), 357-375. doi: 10.1016/j.bbamem.2007.11.008

Huang, L., Chen, D., Wang, L., Lin, C., Ma, C., Xi, X., et al. (2017). Dermaseptin-PH: a novel peptide with antimicrobial and anticancer activities from the skin secretion of the south american orange-legged leaf frog, Pithecopus (Phyllomedusa) hypochondrialis. Molecules 22 (10), 1805. doi: 10.3390/ molecules 22101805

Hui, L. I. N. G., Leung, K. E. I. T. H., and Chen, H. M. (2002). The combined effects of antibacterial peptide cecropin A and anti-cancer agents on leukemia cells. Anticancer Res. 22 (5), 2811-2816.

Jiang, Z., Vasil, A. I., Vasil, M. L., and Hodges, R. S. (2014). Specificity determinants" improve therapeutic indices of two antimicrobial peptides piscidin 1 and dermaseptin s4 against the gram-negative pathogens Acinetobacter baumannii and Pseudomonas aeruginosa. Pharmaceuticals (Basel) 7 (4), 366-391. doi: 10.3390/ph7040366

Joo, H. S., Fu, C. I., and Otto, M. (2016). Bacterial strategies of resistance to antimicrobial peptides. Philos. Trans. R. Soc. B: Biol. Sci. 371 (1695), 20150292.

Konig, E., Bininda-Emonds, O. R., and Shaw, C. (2015). The diversity and evolution of anuran skin peptides. Peptides 63, 96-117. doi: 10.1016/j. peptides.2014.11.003

Krugliak, M., Feder, R., Zolotarev, V. Y., Gaidukov, L., Dagan, A., Ginsburg, H., et al. (2000). Antimalarial activities of dermaseptin S4 derivatives. Antimicrob. Agents Chemother. 44 (9), 2442-2451. doi: 10.1128/aac.44.9.2442-2451.2000

Laughlin, T. F., and Ahmad, Z. (2010). Inhibition of Escherichia coli ATP synthase by amphibian antimicrobial peptides. Int. J. Biol. Macromol. 46 (3), 367-374. doi: 10.1016/j.ijbiomac.2010.01.015

Laxminarayan, R., Duse, A., Wattal, C., Zaidi, A. K., Wertheim, H. F., Sumpradit, N., et al. (2013). Antibiotic resistance-the need for global solutions. Lancet Infect. Dis. 13 (12), 1057-1098. doi: 10.1016/S1473-3099(13)70318-9

Leban, V., Kozelj, G., and Brvar, M. (2016). The syndrome of inappropriate antidiuretic hormone secretion after giant leaf frog (Phyllomedusa bicolor) venom exposure. Toxicon 120, 107-109. doi: 10.1016/j.toxicon.2016.07.007

Leite, J. R., Silva, L. P., Rodrigues, M. I., Prates, M. V., Brand, G. D., Lacava, B. M., et al. (2005). Phylloseptins: a novel class of anti-bacterial and anti-protozoan peptides from the Phyllomedusa genus. Peptides 26 (4), 565-573. doi: 10.1016/j. peptides.2004.11.002 
Leite, J. R., Brand, G. D., Silva, L. P., Kuckelhaus, S. A., Bento, W. R., Araujo, A. L., et al. (2008). Dermaseptins from Phyllomedusa oreades and Phyllomedusa distincta: Secondary structure, antimicrobial activity, and mammalian cell toxicity. Comp. Biochem. Physiol. Mol. Integr. Physiol. 151 (3), 336-343. doi: 10.1016/j.cbpa.2007.03.016

Lequin, O., Ladram, A., Chabbert, L., Bruston, F., Convert, O., Vanhoye, D., et al. (2006). Dermaseptin S9, an alpha-helical antimicrobial peptide with a hydrophobic core and cationic termini. Biochemistry 45 (2), 468-480. doi: 10.1021/bi051711i

Leuschner, C., and Hansel, W. (2004). Membrane disrupting lytic peptides for cancer treatments. Curr. Pharm. Des. 10 (19), 2299-2310.

Li, K., Horng, H., Lynch, K., and Smollin, C. G. (2018). Prolonged toxicity from Kambo cleansing ritual. Clin. Toxicol. 56 (11), 1165-1166. doi: 10.1080/ 15563650.2018.1457153

Liu, J., Wu, Q., Li, L., Xi, X., Wu, D., Zhou, M., et al. (2017). Discovery of phylloseptins that defense against gram-positive bacteria and inhibit the proliferation of the non-small cell lung cancer cell line, from the skin secretions of Phyllomedusa frogs. Molecules 22 (9), 1428. doi: 10.3390/ molecules22091428

Lorin, C., Saidi, H., Belaid, A., Zairi, A., Baleux, F., Hocini, H., et al. (2005). The antimicrobial peptide dermaseptin S4 inhibits HIV-1 infectivity in vitro. Virology 334 (2), 264-275. doi: 10.1016/j.virol.2005.02.002

Marenah, L., Shaw, C., Orr, D. F., McClean, S., Flatt, P. R., and Abdel-Wahab, Y. H. (2004). Isolation and characterisation of an unexpected class of insulinotropic peptides in the skin of the frog Agalychnis litodryas. Regul. Pept. 120, 33-38. doi: 10.1016/j.regpep.2004.02.007

Marynka, K., Rotem, S., Portnaya, I., Cogan, U., and Mor, A. (2007). In vitro discriminative antipseudomonal properties resulting from acyl substitution of N-terminal sequence of dermaseptin s4 derivatives. Chem. Biol. 14 (1), 75-85. doi: 10.1016/j.chembiol.2006.11.009

Mechlia, M. B., Belaid, A., Castel, G., Jallet, C., Mansfield, K. L., Fooks, A. R., et al. (2018). Dermaseptins as potential antirabies compounds. Vaccine 37 (33), 4694-4700. doi: 10.1016/j.vaccine.2018.01.066

Medeiros, K. A., Joanitti, G. A., and Silva, L. P. (2014). Chitosan nanoparticles for dermaseptin peptide delivery toward tumor cells in vitro. Anticancer Drugs 25 (3), 323-331. doi: 10.1097/CAD.0000000000000052

Melo, M. N., and Castanho, M. A. (2012). The mechanism of action of antimicrobial peptides: Lipid Vesicles vs Bacteria. Front. Immunol. 3, 236. doi: 10.3389/fimmu.2012.00236

Mor, A., and Nicolas, P. (1994). Isolation and structure of novel defensive peptides from frog skin. Eur. J. Biochem. 15;219 (1-2), 145-154. doi: 10.1111/j.14321033.1994.tb19924.x

Mor, A., Nguyen, V. H., Delfour, A., Migliore-Samour, D., and Nicolas, P. (1991). Isolation, amino acid sequence, and synthesis of dermaseptin, a novel antimicrobial peptide of amphibian skin. Biochemistry 30 (36), 8824-8830. doi: 10.1046/j.1432-1327.2000.01514.x

Mor, A., Amiche, M., and Nicolas, P. (1994a). Structure, synthesis, and activity of dermaseptin $b$, a novel vertebrate defensive peptide from frog skin: relationship with adenoregulin. Biochemistry 33 (21), 6642-6650. doi: 10.1021/bi00187a034

Mor, A., Hani, K., and Nicolas, P. (1994b). The vertebrate peptide antibiotics dermaseptins have overlapping structural features but target specific microorganisms. J. Biol. Chem. 269 (50), 31635-31641.

Morton, C. O., Dos Santos, S. C., and Coote, P. (2007). An amphibian-derived, cationic, alpha-helical antimicrobial peptide kills yeast by caspase-independent but AIF-dependent programmed cell death. Mol. Microbiol. 65 (2), 494-507. doi: 10.1111/j.1365-2958.2007.05801.x

Navon-Venezia, S., Feder, R., Gaidukov, L., Carmeli, Y., and Mor, A. (2002). Antibacterial properties of dermaseptin S4 derivatives with in vivo activity. Antimicrob. Agents Chemother. 46 (3), 689-694. doi: 10.1128/aac.46.3. 689-694.2002

Nicolas, P., and Amiche, M. (2006). “The dermaseptins," in Handbook of Biologically Active Peptides. Ed. A. J. Kastin (Cambridge Massachusetts: Academic Press), 295-304.

Nicolas, P., and El Amri, C. (2009). The dermaseptin superfamily: a gene-based combinatorial library of antimicrobial peptides. Biochim. Biophys. Acta 1788 (8), 1537-1550. doi: 10.1016/j.bbamem.2008.09.006

Park, C. B., Kim, H. S., and And Kim, S. C. (1998). Mechanism of action of the antimicrobial peptide buforin II: buforin II kills microorganisms by penetrating the cell membrane and inhibiting cellular functions. Biochem. Biophys. Res. Commun. 244 (1), 253-257. doi: 10.1006/bbrc.1998.8159

Pogorzelska, J., and Lapinski, T. W. (2017). Toxic hepatitis caused by the excretions of the Phyllomedusa bicolor frog - a case report. Clin. Exp. Hepatol. 3 (1), 33-34. doi: 10.5114/ceh.2017.65228

Porat, Y., Marynka, K., Tam, A., Steinberg, D., and Mor, A. (2006). Acyl-substituted dermaseptin S4 derivatives with improved bactericidal properties, including on oral microflora. Antimicrob. Agents Chemother. 50 (12), 4153-4160. doi: 10.1128/AAC.00750-06

Pouny, Y., Rapaport, D., Mor, A., Nicolas, P., and Shai, Y. (1992). Interaction of antimicrobial dermaseptin and its fluorescently labeled analogues with phospholipid membranes. Biochemistry 31 (49), 12416-12423. doi: 10.1021/ bi00164a017

Rivero, M., Furman, N., Mencacci, N., Picca, P., Toum, L., Lentz, E., et al. (2012). Stacking of antimicrobial genes in potato transgenic plants confers increased resistance to bacterial and fungal pathogens. J. Biotechnol. 157 (2), 334-343. doi: 10.1016/j.jbiotec.2011.11.005

Rotem, S., Radzishevsky, I., and Mor, A. (2006). Physicochemical properties that enhance discriminative antibacterial activity of short dermaseptin derivatives. Antimicrob. Agents Chemother. 50 (8), 2666-2672. doi: 10.1128/AAC.00030-06

Rydlo, T., Rotem, S., and Mor, A. (2006). Antibacterial properties of dermaseptin S4 derivatives under extreme incubation conditions. Antimicrob. Agents Chemother. 50 (2), 490-497. doi: 10.1128/AAC.50.2.490-497.2006

Savoia, D., Donalisio, M., Civra, A., Salvadori, S., and Guerrini, R. (2010). In vitro activity of dermaseptin S1 derivatives against genital pathogens. APMIS 118 (9), 674-680. doi: 10.1111/j.1600-0463.2010.02637.x

Schittek, B., Paulmann, M., Senyurek, I., and Steffen, H. (2008). The role of antimicrobial peptides in human skin and in skin infectious diseases. Infect. Disord. Drug Targets 8 (3), 135-143. doi: 10.2174/1871526510808030135

Shai, Y. (1999). Mechanism of the binding, insertion and destabilization of phospholipid bilayer membranes by $\alpha$-helical antimicrobial and cell nonselective membrane-lytic peptides. Biochim. Biophys. Acta 1462, 55-70. doi: 10.1016/s0005-2736(99)00200-x

Shams, M. V., Nazarian-Firouzabadi, F., Ismaili, A., and ShirzadianKhorramabad, R. (2019). Production of a Recombinant Dermaseptin Peptide in Nicotiana tabacum Hairy Roots with Enhanced Antimicrobial Activity. Mol. Biotechnol. 61 (4), 241-252. doi: 10.1007/s12033-019-00153-x

Shi, D., Hou, X., Wang, L., Gao, Y., Wu, D., Xi, X., et al. (2016). Two novel dermaseptin-like antimicrobial peptides with anticancer activities from the skin secretion of Pachymedusa dacnicolor. Toxins 8 (5), 144. doi: 10.3390/ toxins 8050144

Silva, L. R., Batista, C. V. F., Prates, M. V., Gordo, M., and Bloch, C. (2000). A new antimicrobial peptide homologous to the dermaseptins isolated from Phyllomedusa tarsius. Toxicon 38, 487595.

Strahilevitz, J., Mor, A., Nicolas, P., and Shai, Y. (1994). Spectrum of antimicrobial activity and assembly of dermaseptin-b and its precursor form in phospholipid membranes. Biochemistry 33 (36), 10951-10960. doi: 10.1021/bi00202a014

Tan, Y., Chen, X., Ma, C., Xi, X., Wang, L., Zhou, M., et al. (2018). Biological activities of cationicity-enhanced and hydrophobicity-optimized analogues of an antimicrobial peptide, dermaseptin-PS3, from the Skin Secretion of Phyllomedusa sauvagii. Toxins 10 (8), 320. doi: 10.3390/toxins 10080320

Tanphaichitr, N., Srakaew, N., Alonzi, R., Kiattiburut, W., Kongmanas, K., Zhi, R., et al. (2016). Potential use of antimicrobial peptides as vaginal spermicides/ microbicides. Pharmaceuticals 9 (1), 13. doi: 10.3390/ph9010013

Thompson, A. H., Bjourson, A. J., Orr, D. F., Shaw, C., and McClean, S. (2007). A combined mass spectrometric and cDNA sequencing approach to the isolation and characterization of novel antimicrobial peptides from the skin secretions of Phyllomedusa hypochondrialis azurea. Peptides 28, 1331-1343. doi: 10.1016/j. peptides.2007.05.001

Utsugi, T., Schroit, A. J., Connor, J., Bucana, C. D., and Fidler, I. J. (1991). Elevated expression of phosphatidylserine in the outer membrane leaflet of human tumor cells and recognition by activated human blood monocytes. Cancer Res. 51 (11), 3062-3066.

van Zoggel, H., Carpentier, G., Dos Santos, C., Hamma-Kourbali, Y., Courty, J., Amiche, M., et al. (2012). Antitumor and angiostatic activities of the antimicrobial peptide dermaseptin B2. PloS One 7 (9), e44351. doi: 10.1371/journal.pone. 0044351 
van Zoggel, H., Hamma-Kourbali, Y., Galanth, C., Ladram, A., Nicolas, P., Courty, J., et al. (2010). Antitumor and angiostatic peptides from frog skin secretions. Amino Acids 42 (1), 385-395. doi: 10.1007/s00726-010-0815-9

Vanhoye, D., Bruston, F., Nicolas, P., and Amiche, M. (2003). Antimicrobial peptides from hylid and ranin frogs originated from a 150-million-year-old ancestral precursor with a conserved signal peptide but a hypermutable antimicrobial domain. Eur. J. Biochem. 270, 2068-2081. doi: 10.1046/j.1432-1033.2003.03584.x

Vouille, V., Amiche, M., and Nicolas, P. (1997). Structure of genes for dermaseptins $\mathrm{B}$, antimicrobial peptides from frog skin. Exon 1-encoded prepropeptide is conserved in genes for peptides of highly different structures and activities. FEBS Lett. 414, 27-32. doi: 10.1016/s0014-5793(97)00972-1

Wang, G., Watson, K. M., Peterkofsky, A., and Buckheit, R. W. Jr. (2010). Identification of novel human immunodeficiency virus type 1-inhibitory peptides based on the antimicrobial peptide database. Antimicrob. Agents Chemother. 54 (3), 1343-1346. doi: 10.1128/AAC.01448-09

Wechselberger, C. (1998). Cloning of cDNAs encoding new peptides of the dermaseptin family, Biochim. Biophys. Acta 1388, 279-283. doi: 10.1016/ s0167-4838(98)00202-7

Yang, J., Tsutsumi, H., Furuta, T., Sakurai, M., and Mihara, H. (2014). Interaction of amphiphilic alpha-helical cell-penetrating peptides with heparan sulfate. Org. Biomol. Chem. 12 (26), 4673-4681. doi: 10.1039/c4ob00673a

Yeaman, M. R., and Yount, N. Y. (2003). Mechanisms of antimicrobial peptide action and resistance. Pharmacol. Rev. 55 (1), 27-55. doi: 10.1124/pr.55.1.2

Yevtushenko, D. P., and Misra, S. (2019). Enhancing disease resistance in poplar through modification of its natural defense pathway. Plant Mol. Biol. 100, 481. doi: 10.1007/s11103-019-00874-2
Zairi, A., Belaid, A., Gahbiche, A., and Hani, K. (2005). Spermicidal activity of dermaseptins. Contraception 72 (6), 447-453. doi: 10.1016/j. contraception.2005.06.055

Zairi, A., Ferrieres, L., Latour-Lambert, P., Beloin, C., Tangy, F., Ghigo, J. M., et al. (2014). In vitro activities of dermaseptins K4S4 and K4K20S4 against Escherichia coli, Staphylococcus aureus, and Pseudomonas aeruginosa planktonic growth and biofilm formation. Antimicrob. Agents Chemother. 58 (4), 2221-2228. doi: 10.1128/AAC.02142-13

Zasloff, M. (2002). Antimicrobial peptides in health and disease. New Engl. J. Med. 347 (15), 1199-1200. doi: 10.1056/NEJMe020106

Zhu, H., Ding, X., Li, W., Lu, T., Ma, C., Xi, X., et al. (2018). Discovery of two skinderived dermaseptins and design of a TAT-fusion analogue with broad-spectrum antimicrobial activity and low cytotoxicity on healthy cells. PeerJ 6, e5635. doi: $10.7717 /$ peerj. 5635

Conflict of Interest: The authors declare that the research was conducted in the absence of any commercial or financial relationships that could be construed as a potential conflict of interest.

Copyright (c) 2019 Bartels, Dekker and Amiche. This is an open-access article distributed under the terms of the Creative Commons Attribution License (CC $B Y)$. The use, distribution or reproduction in other forums is permitted, provided the original author(s) and the copyright owner(s) are credited and that the original publication in this journal is cited, in accordance with accepted academic practice. No use, distribution or reproduction is permitted which does not comply with these terms. 